\title{
ANALISIS PENGAKUAN PENDAPATAN DAN BEBAN PADA PT. BANK PERKREDITAN RAKYAT PRISMA DANA MANADO
}

\author{
Ferry Christian $\operatorname{Ham}^{1}$, Herman Karamoy ${ }^{2}$, Stanly Alexander ${ }^{3}$ \\ 1,2,3 Jurusan Akuntansi, Fakultas Ekonomi dan Bisnis, Universitas Sam Ratulangi, Jl. Kampus Bahu, Manado, \\ 95115, Indonesia \\ E-mail : ferryham19@gmail.com
}

\begin{abstract}
Revenue is the value derived from the activities of a company known by different names such as sales, service income, interest, profit sharing, royalties and rent. Expenses represent a reduction in usage life during an accounting period in the form of cash outflow or loss of assets or occurrence of liabilities resulting in a decrease in equity not related to the distribution to investors. Recognition of income at PT. Bank Credit Prisma Dana Manado recognizes income based on the accrual basis and cash basis method, where accrual basis income is recognized as incurred while cash base income is recognized upon receipt of cash. Load recognition at PT. Bank Credit Prisma Dana Manado recognize expenses based on the accrual basis method, in which the accrual basis is recognized as an expense in the statements of income in the period in which they are incurred. The research method used in this thesis research is descriptive method whose purpose every data collected is analyzed and then drawn a conclusion and research type used is qualitative descriptive. The results obtained that the recognition of income and expenses at PT. Bank Credit Prisma Dana Manado Rural Bank is in compliance with PSAK No. 23, because PSAK No. 23 only recognizes two methods: accrual basis and cash base.
\end{abstract}

Keywords: Analysis, Revenue Recognition, Expense Recognition.

\section{PENDAHULUAN}

Perusahaan adalah suatu organisasi dimana sumber daya (input) seperti bahan baku dan tenaga kerja diproses untuk meghasilkan barang atau jasa (output) bagi pelanggan, yang memanfaatkan berbagai macam sumber-sumber ekonomi yang terbatas untuk dapat memenuhi kebutuhan dengan cara yang menguntungkan. Tujuan utama dari perusahaan baik yang berskala besar maupun kecil adalah agar dapat mempertahankan kelangsungan hidup perusahaan, berkembang dan memperoleh laba maksimal. Agar tujuan ini tercapai, sumber daya yang dimiliki oleh perusahaan harus dikelola secara efektif dan efisien guna menghindari pengangguran dan pemborosan dana. Strategi Perusahaan sangat penting dalam penyusunan dan penyajian laporan keuangan perusahaan karena laporan keuangan digunakan untuk mengevaluasi kinerja perusahaan dalam mengambil keputusan.

Tujuan utama dari pengakuan pendapatan dan beban adalah untuk menetukan kapan suatu pengahasilan diakui sebagai pendapatan dan biaya diakui sebagai beban. Adapun metode yang digunakan yaitu cash basis dan accrual basis. Apabila cash basis yang digunakan maka pendapatan diakui pada saat kas diterima dan beban dilaporkan pada saat kas dibayarkan. Dan apabila accrual basis yang digunakan maka pendapatan diakui pada saat pendapatan itu dihasilkan walaupun secara fisik kas belum diterima dan beban diakui saat beban terjadi tanpa memperhatikan arus kas keluar dalam usaha menghasilkan pendapatan.

Pengakuan pendapatan dan beban adalah untuk mendapatkan perhitungan laba yang wajar maka sangat penting diperhatikan mengenai penentuan dasar untuk menentukan pengakuan pendapatan dan beban. 
Dengan demikian pendapatan dan beban yang akan diakui dalam suatu tahun tertentu dipengaruhi oleh pendapatan dan beban yang sudah diakui. Penyusunan dalam laporan laba rugi semua pendapatan ataupun beban yang dilaporkan merupakan pendapatan dan beban untuk periode yang bersangkutan. Pendapatan yang telah menjadi hak tetapi belum diterima ataupun beban yang telah menjadi kewajiban tetapi belum dibayar harus dilaporkan pada periode yang bersangkutan. Sedangkan pendapatan yang belum merupakan hak tetapi sudah diterima ataupun beban yang mempunyai kegunaan pada masa yang akan datang tetapi sudah dibayar harus dikeluarkan pada periode yang bersangkutan. Sehubungan dengan hal tersebut perlu dilakukan penyesuaian atas pendapatan maupun beban agar laporan keuangan yang disajikan dapat dinyatakan secara wajar dan sesuai dengan prinsip akuntansi yang berlaku umum.

Bank Perkreditan Rakyat (BPR) Prisma Dana Manado, oleh Info Bank memberi predikat Sangat Bagus dan masuk salah satu BPR Terbaik Tahun 2012 atas kinerja keuangan dan selalu mengikuti perubahan teknologi dan regulasi. Landasan PT. BPR Prisma Dana adalah disamping berfungsi sebagai Bank Perkreditan Rakyat, akan tetapi visi dan misi BPR Prisma Dana berbeda dengan BPR- BPR lainnya, karena unsur daerah (regional) harus mendapat perhatian yang lebih besar dalam rangka meningkatkan taraf hidup rakyat.

\section{TINJAUAN PUSTAKA}

\subsection{Akuntansi}

\subsubsection{Pengertian Akuntansi}

Akuntansi adalah aktivitas jasa, yang berfungsi untuk menyediakan informasi kuantitatif, terutama tentang keputusan ekonomi dalam rangka untuk membuat pilihan alternatif (Stice dan Skousen, 2011:8). Sedangkan, akuntansi adalah suatu sistem yang mencatat dan menggolongkan transaksi dan kejadian-kejadian yang umumnya bersifat keuangan dan termasuk menafsirkan hasil-hasilnya dengan cara tertentu dan dengan ukuran moneter (Harahap, 2011:15). Informasi akuntansi pada dasarnya menyajikan informasi ekonomi kepada banyak pihak yang memerlukan. Adapun pihak yang memerlukan informasi akuntansi terbagi ke dalam 2 (dua) jenis yaitu pihak internal dan pihak eksternal. Pihak eksternal terdiri dari pemegang saham, pemerintah, dan masyarakat sedangkan pihak internal terdiri dari pihak manajemen perusahaan yang bersangkutan.

\subsection{Pendapatan}

\subsubsection{Pengertian Pendapatan}

Pendapatan adalah arus masuk aktiva atau peningkatan lainnya atas aktiva atau penyelesaian kewajiban entitas dari pengiriman barang, pemberian jasa, atau aktivitas lainnya yang merupakan operasi utama atau operasi sentral perusahaan (Hery, 2013:49). Hendriksen (2002:374) menyatakan bahwa pendapatan merupakan hasil dari suatu perusahaan, hal itu biasanya diukur dalam satuan harga pertukaran yang berlaku. Pendapatan sangat berperan aktif bagi suatu usaha, semakin besar pendapatan yang diperoleh maka semakin besar kemampuan suatu usaha untuk membiayai segala pengeluaran dan kegiatan-kegiatan yang akan dilakukan. Kondisi seseorang dapat diukur dengan menggunakan konsep pendapatan yang menujukkan jumlah seluruh uang yang diterima oleh seseorang atau rumah tangga selama jangka waktu tertentu (Samuelson dan Nordhaus dalam Prakoso, 2013:7).

\subsubsection{Jenis-jenis Pendapatan}

Secara garis besar pendpaatan digolongkan menjadi tiga golongan (Suparmoko dalam Artaman, 2015:11) yaitu:

1. Gaji dan Upah. Imbalan yang diperoleh setelah orang tersebut melakukan pekerjaan untuk orang lain yang diberikan dalam waktu satu hari, satu minggu maupun satu bulan.

2. Pendapatan dari usaha sendiri, yaitu nilai total yang diperoleh dari hasil produksi yang telah dikurangi dengan beban-beban yang dibayar dan usaha ini merupakan usaha milik 
sendiri atau keluarga dan tenaga kerja berasal dari anggota keluarga sendiri, nilai sewa kapital milik sendiri dan semua biaya ini biasanya tidak diperhitungkan.

3. Pendapatan dari usaha lain. Pendapatan yang diperoleh tanpa mencurahkan tenaga kerja dan ini biasanya merupakan pendapatan sampingan antara lain yaitu pendapatan dari hasil menyewakan aset yang dimiliki seperti rumah, ternak dan barang lain, bunga dari uang, sumbangan dari pihak lain dan pendapatan dari pensiun.

\subsubsection{Pengukuran Pendapatan}

Pengukuran pendapatan dengan satuan atau ukuran moneter dan penetapan waktu bahwa pendapatan tersebut dapat dilaporkan sebagai pendapatan.

Suwardjono (2013:34) pengakuan pendapatan adalah pencatatan jumlah secara resmi kedalam sistem akuntansi sehingga jumlah tersebut tere fleksi dalam statemen keuangan. Pendapatan dapat diakui apabila memenuhi kualitas keterukuran (measurability) dan keandalan (reliability). Berdasarkan waktu dan jenis usahanya, pengakuan pendapatan tidak dapat disamakan satu sama lain. Perusahaan yang bergerak di bidang yang berbeda akan mempunyai cara yang berbeda dalam pengakuan dan pencatatan pendapatannya. Pengakuan pendapatan tidak selalu dilakukan saat penjualan telah terjadi.

\subsubsection{Unsur-unsur Pendapatan}

Unsur-unsur pendapatan yang dimaksud adalah asal dari pada pendapatan itu diperoleh, dimana unsur-unsur tersebut meliputi:

1. Pendapatan hasil produksi barang atau jasa.

2. Imbalan yang diterima atas penggunaan aktiva atau sumber-sumber ekonomis perusahaan oleh pihak lain.

3. Penjualan aktiva diluar barang dagangan merupakan unsur-unsur pendapatan lain-lain suatu perusahaan.

\subsubsection{Sumber-sumber Pendapatan}

Pendapatan diketahui bahwa sumber pendapatan itu dapat melalui beberapa aspek dimana dapat dijabarkan menjadi tiga sumber pendapatan yaitu:

1. Pendapatan operasional, yaitu pendapatan yang berasal dari aktivitas utama perusahaan.

2. Pendapatan non operasional, pendapatan yang tidak terkait dengan aktivitas perusahaan, yaitu pendapatan yang didapat dari faktor eksternal.

3. Pendapatan luar biasa (extra ordinary), yaitu pendapatan yang tak terduga dimana pendapatan ini tidak sering terjadi dan biasanya diharapkan tidak terulang lagi dimasa yang akan datang. (Baridwan, 2014:28-35).

\subsection{Beban}

\subsubsection{Pengertian Beban}

Beban adalah aliran keluar terukur dari barang atau jasa, yang kemudian ditandingkan dengan pendapatan untuk menentukan laba atau sebagai penurunan dalam aktiva bersih sebagai akibat dari penggunaan jasa ekonomis dalam menciptakan pendapatan atau pengenaan pajak oleh badan pemerintah (Soemarso, 2013:29). Sedangkan, menurut Kieso, Weygandt, dan Warfield (2016:14) beban memiliki pengertian penggunaan lain dari aset atau jaminan utang dalam periode tertentu untuk mengirimkan, memproduksi barang, pemberian pelayanan atau lain sebagainya yang berkaitan dengan operasi utama perusahaan yang sedang berlangsung.

Soemarso (2013:226) beban dapat dikelompokkan menjadi:

1. Beban penjualan (selling expenses)

Beban penjualan merupakan biaya yang dikeluarkan guna memperkenalkan barang kepada masyarakat dan memasarkan barang tersebut seperti kegiatan promosi, penjualan dan pengangkutan barang-barang yang dijual.

2. Beban Administrasi dan Umum (General and Administratif expenses)

Beban yang bersifat umum dalam perusahaan. 
3. Beban Lain-Lain ( Other Expense)

Seluruh beban yang tidak ada hubungan secara langsung dan pasti dengan kegiatan utama perusahaan (perdagangan) dikelompokkan kedalam beban lain-lain (other expenses) atau beban non-usaha (non operating expenses).

\subsubsection{Pengakuan Beban}

Pengakuan beban terjadi yaitu pada saat beban tersebut dikeluarkan, beberapa jumlahnya dan bagaimana hubungan beban yang dikeluarkan tersebut dalam kegiatan operasi perusahaan. Pengakuan bebannya menggunakan metode accrual basis, yaitu ditetapkan berdasarkan kontrak dengan masa manfaatnya. Konsep accrual basis beban tidak jauh berbeda dengan konsep accrual basis pada pendapatan. Dalam konsep accrual basis dibutuhkan pengawasan beban yang memiliki sistem atau prosedur yang harus diperhatikan oleh perusahaan seperti semua beban yang dikeluarkan yang ada hubungannya dengan aktivitas perusahaan yang sedang dikerjakan yang ada otorisasinya dari bagian keuangan.

\subsubsection{Pengukuran Beban}

Penilaian aktiva dan hutang dapat dinilai berdasarkan penilaian aktiva yang dapat diukur atas dasar jumlah rupiah. Sehingga, pengukuran biaya dapat didasarkan pada:

1. Cost historis, merupakan jumlah kas atau setara kas yang dikorbankan untuk mendapatkan aktiva. Biaya yang diukur atas cost historis untuk jenis aktiva seperti: gedung, peralatan dan sebagainya.

2. Cost pengganti / cost masukan terkini (replacement cost / curent input cost). Untuk memperoleh aktiva yang sejenis dalam kondisi yang sama, suatu entitas memperlihatkan jumlah rupiah harga pertukaran yang harus dikorbankan. Contohnya: penilaian untuk persediaan.

3. Setara kas (cash equivalent), menjual setiap jenis aktiva di pasar bebas dalam kondisi perusahaan normal merupakan rupiah yang dikeluarkan.

\subsubsection{Penilaian Beban}

Langkah-langkah penerapan penilaian pendekatan biaya:

1. Menentukan biaya pembangunan baru bangunan.

2. Memperkirakan besarnya penyusutan atau depresiasi bangunan.

3. Nilai bangunan diperoleh dari mengurangi biaya pembangunan baru bangunan dengan penyusutan (depresiasi).

4. Menentukan nilai tanah dimana bangunan itu didirikan.

5. Nilai pasar wajar property diperoleh dari menambahkan nilai bangunan dan nilai tanah.

\subsubsection{Pengungkapan Beban}

Di dalam neraca, jumlah kewajiban yang timbul sebagai akibat perbedaan antara jumlah pendanaan yang telah dilakukan oleh pemberi kerja sejak pembentuk program dengan jumlah yang diakui sebagai beban selama periode yang sama. Di dalam laporan laba rugi, jumlah diakui sebagai beban selama periode yang bersangkutan.

\subsubsection{Penggunaan Beban}

Setiap perusahaan tentunya akan mengeluarkan beban untuk menyelesaikan kegiatan operasional perusahaan untuk menjalankan kegiatan usaha. Setiap beban yang dikeluarkan tergantung pada kegiatan dan ruang lingkup usaha suatu perusahaan.

\subsection{Pengakuan}

\subsubsection{Pengertian Pengakuan}

Untuk mengakui eksistensi suatu wilayah tertentu yang dihuni suatu masyarakat yang secara politis terorganisir dengan perbuatan bebas yang dilakukan oleh suatu negara dan tidak terikat oleh negara yang lebih dulu ada serta untuk memandang wilayah itu sebagai salah satu anggota masyarakat internasional, dan suatu negara harus mampu menjalankan kewajiban-kewajiban menurut hukum internasional. 


\subsubsection{Fungsi Pengakuan}

Masalah pengakuan merupakan salah satu bagian yang paling sulit dalam hukum internasional walaupun terlihat sederhana karena dilihat secara intrinsic bukan hanya dilihat dari segi dasar-dasar.

\subsubsection{Bentuk-bentuk Pengakuan}

Dalam tulisan ini akan dibatasi pada pembahasan bentuk-bentuk pengakuan terpenting yang selalu menarik perhatian umum, yaitu:

1. Pengakuan negara baru

2. Pengakuan pemerintah baru

3. Pengakuan sebagai pemberontak

5. Pengakuan beligerensi

6. Pengakuan sebagai bangsa

7. Pengakuan hak-hak teritorial dan situasi internasional baru

\subsubsection{Pengakuan Beban}

Pengakuan pendapatan pada dasarnya sejalan dengan pengakuan biaya yang secara umum dapat dirumuskan berdasarkan konsep penandingan (matching). Untuk mengatasi berbagai perbedaan pendapat tentang pengakuan biaya, aturan tertentu dikeluarkan oleh badan berwenang untuk mengakui biaya.

\subsubsection{Pengakuan Pendapatan}

Konsep objektivitas dalam akuntansi umumnya merupakan dasar atas pengakuan suatu jumlah rupiah dimana jumlah rupiah tersebut dapat diukur secara cukup pasti dan ada keterlibatan pihak independen dalam pengukurannya.

\subsection{PSAK No. 23: Pendapatan}

Pernyataan Standar Akuntansi Keuangan 23 dilengkapi dengan lampiran yang bukan merupakan bagian dari PSAK 23. Seluruh paragraf dalam pernyataan ini memiliki kekuatan mengatur yang sama. PSAK 23 harus dibaca dalam konteks tujuan pengaturan dan kerangka dasar penyusunan dan penyajian laporan keuangan.

\subsubsection{Tujuan}

Permasalahan utama dalam akuntansi untuk pendapatan adalah menentukan saat pengakuan pendapatan. Manfaat ekonomi masa depan akan mengalir ke perusahaan dan dapat didapat diukur dengan andal, merupakan dasar dari pengakuan pendapatan.

\subsection{Konsep Penyajian Laporan Keuangan}

Laporan keuangan adalah hasil akhir dari proses akuntansi sebuah perusahaan yang memberikan informasi keuangan suatu perusahaan yang berguna bagi pihak internal maupun eksternal perusahaan.

Komponen laporan keuangan lengkap menurut PSAK 1 (2015) terdiri dari:

1. Laporan posisi keuangan pada akhir periode.

2. Laporan laba rugi dan penghasilan komprehensif lain selama periode.

3. Laporan perubahan ekuitas selama periode.

4. Laporan arus kas selama periode.

5. Ringkasan kebijakan akuntansi yang signifikan dan informasi penjelasan lain tercantum dalam catatan atas laporan keuangan

\subsubsection{Tujuan Laporan Keuangan}

Laporan keuangan bermanfaat bagi kalangan pengguna laporan keuangan dalam pengambilan suatu keputusan ekonomi, memberikan informasi mengenai posisi keuangan serta kinerja keuangan.

\subsubsection{Komponen Laporan Keuangan}

Laporan keuangan yang lengkap terdiri dari komponen berikut ini:

1. Laporan posisi keuangan pada akhir periode.

2. Laporan laba rugi komprehensif selama periode. 
3. Laporan perubahan ekuitas selama periode.

4. Laporan arus kas selama periode.

5. Ringkasan kebijakan akuntansi penting dan informasi penjelasan lainnya dicantumkan dalam catatan laporan keuangan; dan

6. Laporan posisi keuangan awal periode komparatif, laporan yang disajikan ketika entitas menerapkan suatu kebijakan akuntansi secara retrospektif.

\subsection{Penelitian terdahulu}

Penelitian terdahulu yang penulis jadikan sebagai bahan pertimbangan dalam melakukan penelitian di PT. Bank Perkreditan Rakyat Prisma Dana Manado. Penelitian yang dilakukan oleh Rismansyah dan Nurlaili tahun 2015, tentang Analisis Pengakuan Pendapatan dan Beban pada PT. WAHANA BUMI RIAU Cabang Palembang, menyatakan bahwa terdapat perbedaan dalam pencatatan jurnal pendapatan dan beban, serta berpengaruh pada pendapatan dan beban dimana pada metode kontrak selesai pendapat dan beban yang terjadi tidak mencerminkan keadaan yang sesungguhnya pada perusahaan berbeda dengan metode persentase penyelesaian, pendapatan dan beban yang diperoleh mencerminkan kondisi keuangan yang sesungguhnya terjadi pada perusahaan. Perusahaan menggunakan metode pengakuan pendapatan dan beban yang sesuai dengan Standar Akuntansi Keuangan PSAK No. 34 .

\section{METODE PENELITIAN}

\subsection{Jenis Penelitian}

Penelitian yang dilakukan merupakan penelitian deskriptif. Suatu penelitian yang diperuntukan untuk menggambarkan fenomena yang ada, baik fenomena yang bersifat alamiah atau rekayasa manusia disebut dengan penelitian deskriptif (Sukmadinata : 2013).

Secara sederhana Penelitian Deskriptif adalah Penelitian yang menjelaskan setiap data yang diperoleh, fenomena yang terjadi dan hasil penelitian di lapangan yang ditemukan, dalam bentuk kata-kata yang menceritakan, mengemukakan dan menggambarkan situasi tersebut yang memiliki makna sesuai dengan hasil penelitian yang dilakukan.

Dalam penelitian ini, penulis menggunakan data kualitatif sebagai dasar untuk menganalisis bagaimana pengakuan pendapatan dan beban pada PT. Bank Perkreditan Rakyat Prisma Dana Manado.

\subsection{Waktu dan Tempat Penelitian}

Penelitian ini dilaksanakan pada PT. Bank Perkreditan Rakyat Prisma Dana Manado yang bertempat di Jl. Pierre Tendean Blok A No.1 Marina Plaza, Kota Manado, Sulawesi Utara. Waktu Penelitian dimulai dari Maret sampai dengan bulan April 2018.

\subsection{Prosedur Penelitian}

Mengidentifikasi masalah, menentukan objek penelitian, penyusunan proposal penelitian, pengumpulan data, menganalisis dan mengolah data, hasil penelitian, membuat kesimpulan dan memberikan saran

\subsection{Metode Analisis}

Metode penelitian yang digunakan dalam penelitian ini adalah metode deskriptif. Metode yang menggambarkan hasil penelitian tetapi tidak membuat kesimpulan yang luas disebut dengan metode deskriptif (Sugiyono, 2014:22). Data yang diperoleh mengenai pengakuan pendapatan dan beban menggunakan data laporan keuangan, yaitu data laporan laba rugi tahun 2015 dan 2016. Analisis yang dilakukan mengenai pengakuan pendapatan dan beban sehingga bahasan yang dilakukan yakni bahasan mengenai:

1. Analisis Pengakuan Pendapatan

2. Analisis Pengakuan Beban

Alat analisis yang digunakan untuk menguji pengakuan pendapatan dan beban, yakni menggunakan Pernyataan Standar Akuntansi Keuangan 23 (PSAK 23). 


\section{HASIL ANALISIS DAN PEMBAHASAN}

\subsection{Hasil analisis}

4.1.1 Perlakuan Akuntansi atas Pendapatan pada PT. Bank Perkreditan Rakyat Prisma Dana Manado

Adapun Perlakuan Akuntansi Atas Pendapatan pada PT. Bank Perkreditan Rakyat

Prisma Dana Manado sebagai berikut:

1. Pendapatan Bunga Kontraktual

2. Pendapatan Bunga Provisi

a. Pengakuan

Pengakuan Pendapatan atas pendapatan bunga kontraktual dan pendapatan bunga provisi pada PT. Bank Perkreditan Rakyat Prisma Dana Manado diakui menggunakan metode cash basis dimana pendapatan diakui atau dicatat pada saat kas benar-benar diterima atau adanya penerimaan uang.

b. Pengukuran

Pengukuran pendapatan atas pendapatan bunga kontraktual dan pendapatan bunga provisi pada PT. Bank Perkreditan Rakyat Prisma Dana Manado diukur dengan nilai wajar imbalan yang diterima atau yang dapat diterima.

c. Penyajian

Penyajian pendapatan atas pendapatan bunga kontraktual dan pendapatan bunga provisi ada PT. Bank Perkreditan Rakyat Prisma Dana Manado disajikan dalam Laporan Keuangan Laba Rugi Perusahaan.

d. Pengungkapan

Disamping disajikan dalam Laporan Laba Rugi pendapatan atas pendapatan bunga kontraktual dan pendapatan bunga provisi pada PT. Bank Perkreditan Rakyat Prisma Dana Manado harus diungkapkan pada catatan atas laporan keuangan.

3. Pendapatan Operasional lainya

a. Pengakuan

Pengakuan Pendapatan atas pendapatan operasional lain pada PT. Bank Perkreditan

Rakyat Prisma Dana Manado diakui menggunakan metode accrual basis dimana pada saat manfaat ekonomi yang akan diterima perusahaan dimasa yang akan datang.

b. Pengukuran

Pengukuran pendapatan atas pendapatan operasional lain pada PT. Bank Perkreditan Rakyat Prisma Dana Manado diukur dengan nilai wajar imbalan yang diterima atau yang dapat diterima.

c. Penyajian

Penyajian pendapatan atas pendapatan operasional lain pada PT. Bank Perkreditan Rakyat Prisma Dana Manado disajikan dalam Laporan Keuangan Laba Rugi Perusahaan.

d. Pengungkapan

Disamping disajikan dalam Laporan Laba Rugi pendapatan atas pendapatan operasional lain pada PT. Bank Perkreditan Rakyat Prisma Dana Manado harus diungkapkan pada catatan atas laporan keuangan.

4.1.2 Perlakuan Akuntansi atas Beban pada PT. Bank Perkreditan Rakyat Prisma Dana Manado

Adapun Perlakuan Akuntansi Atas Beban pada PT. Bank Perkreditan Rakyat Prisma

Dana Manado sebagai berikut:

1. Beban Penyisihan dan Penyusutan

a. Pengakuan 
Pengakuan Beban atas Beban Penyisihan dan Penyusutan pada PT. Bank Perkreditan Rakyat Prisma Dana Manado diakui menggunakan metode accrual basis dimana seluruh biaya diakui sebagai beban pada laporan laba rugi di periode terjadinya.

b. Pengukuran

Pengukuran Beban atas Beban Penyisihan dan Penyusutan pada PT. Bank Perkreditan Rakyat Prisma Dana Manado diukur dengan nilai wajar imbalan yang diterima atau yang dapat diterima.

c. Penyajian

Penyajian Beban atas Beban Penyisihan dan Penyusutan pada PT. Bank Perkreditan Rakyat Prisma Dana Manado disajikan dalam Laporan Keuangan Laba Rugi Perusahaan.

d. Pengungkapan

Disamping disajikan dalam Laporan Laba Rugi Beban atas Beban Penyisihan dan Penyusutan pada PT. Bank Perkreditan Rakyat Prisma Dana Manado harus diungkapkan pada catatan atas laporan keuangan.

2. Beban Pemasaran

a. Pengakuan

Pengakuan Beban atas Beban Pemasaran pada PT. Bank Perkreditan Rakyat Prisma Dana Manado diakui menggunakan metode accrual basis dimana seluruh biaya diakui sebagai beban pada laporan laba rugi di periode terjadinya.

b. Pengukuran

Pengukuran Beban atas Beban Pemasaran pada PT. Bank Perkreditan Rakyat Prisma Dana Manado diukur dengan nilai wajar imbalan yang diterima atau yang dapat diterima.

c. Penyajian

Penyajian Beban atas Beban Pemasaran pada PT. Bank Perkreditan Rakyat Prisma Dana Manado disajikan dalam Laporan Keuangan Laba Rugi Perusahaan.

d. Pengungkapan

Disamping disajikan dalam Laporan Laba Rugi Beban atas Beban Pemasaran pada PT. Bank Perkreditan Rakyat Prisma Dana Manado harus diungkapkan pada catatan atas laporan keuangan.

3. Beban Administrasi dan Umum

a. Pengakuan

Pengakuan Beban atas Beban Administrasi dan Umum pada PT. Bank Perkreditan Rakyat Prisma Dana Manado diakui menggunakan metode accrual basis dimana seluruh biaya diakui sebagai beban pada laporan laba rugi di periode terjadinya.

b. Pengukuran

Pengukuran Beban atas Beban Administrasi dan Umum pada PT. Bank Perkreditan Rakyat Prisma Dana Manado diukur dengan nilai wajar imbalan yang diterima atau yang dapat diterima.

c. Penyajian

Penyajian Beban atas Beban Administrasi dan Umum pada PT. Bank Perkreditan Rakyat Prisma Dana Manado disajikan dalam Laporan Keuangan Laba Rugi Perusahaan.

d. Pengungkapan

Disamping disajikan dalam Laporan Laba Rugi Beban atas Beban Administrasi dan Umum pada PT. Bank Perkreditan Rakyat Prisma Dana Manado harus diungkapkan pada catatan atas laporan keuangan. 


\subsection{Pembahasan}

\subsubsection{Analisis Pengakuan Pendapatan PT. Bank Perkreditan Rakyat Prisma Dana Manado}

Pengakuan pendapatan atas pendapatan bunga kontraktual dan pendapatan bunga provisi pada PT. Bank Perkreditan Rakyat Prisma Dana Manado diakui menggunakan metode cash basis dimana Pendapatan diakui atau dicatat pada saat kas benar-benar diterima atau adanya penerimaan uang. Pengukuran pendapatan atas pendapatan bunga kontraktual dan pendapatan bunga provisi pada PT. Bank Perkreditan Rakyat Prisma Dana Manado diukur dengan nilai wajar imbalan yang diterima atau yang dapat diterima. Penyajian pendapatan atas pendapatan bunga kontraktual dan pendapatan bunga provisi ada PT. Bank Perkreditan Rakyat Prisma Dana Manado disajikan dalam Laporan Keuangan Laba Rugi Perusahaan. Disamping disajikan dalam Laporan Laba Rugi pendapatan atas pendapatan bunga kontraktual dan pendapatan bunga provisi pada PT. Bank Perkreditan Rakyat Prisma Dana Manado harus diungkapkan pada catatan atas laporan keuangan, sedangkan pengakuan pendapatan atas pendapatan operasional lain pada PT. Bank Perkreditan Rakyat Prisma Dana Manado diakui menggunakan metode accrual basis dimana pada saat manfaat ekonomi yang akan diterima perusahaan dimasa yang akan datang. Pengukuran pendapatan atas pendapatan operasional lain pada PT. Bank Perkreditan Rakyat Prisma Dana Manado diukur dengan nilai wajar imbalan yang diterima atau yang dapat diterima. Penyajian pendapatan atas pendapatan operasional lain pada PT. Bank Perkreditan Rakyat Prisma Dana Manado disajikan dalam Laporan Keuangan Laba Rugi Perusahaan. Disamping disajikan dalam Laporan Laba Rugi pendapatan atas pendapatan operasional lain pada PT. Bank Perkreditan Rakyat Prisma Dana Manado harus diungkapkan pada catatan atas laporan keuangan.

\subsubsection{Analisis Pengakuan Beban PT. Bank Perkreditan Rakyat Prisma Dana Manado}

Pengakuan Beban atas beban penyisihan dan penyusutan pada PT. Bank Perkreditan Rakyat Prisma Dana Manado diakui menggunakan metode accrual basis dimana seluruh biaya diakui sebagai beban pada laporan laba rugi di periode terjadinya. Pengukuran beban atas beban penyisihan dan penyusutan pada PT. Bank Perkreditan Rakyat Prisma Dana Manado diukur dengan nilai wajar imbalan yang diterima atau yang dapat diterima. Penyajian beban atas beban penyisihan dan penyusutan pada PT. Bank Perkreditan Rakyat Prisma Dana Manado disajikan dalam Laporan Keuangan Laba Rugi Perusahaan. Disamping disajikan dalam Laporan Laba Rugi Beban atas Beban Penyisihan dan Penyusutan pada PT. Bank Perkreditan Rakyat Prisma Dana Manado harus diungkapkan pada catatan atas laporan keuangan. Kedua, yaitu beban pemasaran didalamnya terdapat biaya iklan dan biaya promosi. Pengakuan Beban atas Beban Pemasaran pada PT. Bank Perkreditan Rakyat Prisma Dana Manado mengakui seluruh biaya sebagai beban pada laporan laba rugi di periode terjadinya. Pengukuran Beban atas Beban Pemasaran pada PT. Bank Perkreditan Rakyat Prisma Dana Manado diukur dengan nilai wajar imbalan yang diterima atau yang dapat diterima. Penyajian Beban atas Beban Pemasaran pada PT. Bank Perkreditan Rakyat Prisma Dana Manado disajikan dalam Laporan Keuangan Laba Rugi Perusahaan. Disamping disajikan dalam Laporan Laba Rugi Beban atas Beban Pemasaran pada PT. Bank Perkreditan Rakyat Prisma Dana Manado harus diungkapkan pada catatan atas laporan keuangan. Ketiga, yaitu Beban Administrasi dan Umum yang didalamnya terdapat biaya meterai, beban alat kantor, beban alat kebersihan kantor, beban listrik dan air, beban telepon dan fax, dan biaya fotokopi. Pengakuan Beban atas Beban Administrasi dan Umum pada PT. Bank Perkreditan Rakyat Prisma Dana Manado mengakui seluruh biaya sebagai beban pada laporan laba rugi di periode terjadinya. Pengukuran Beban atas Beban Administrasi dan Umum pada PT. Bank Perkreditan Rakyat Prisma Dana Manado diukur dengan nilai wajar imbalan yang diterima atau yang dapat diterima. Penyajian Beban atas Beban Administrasi dan Umum pada PT. Bank Perkreditan Rakyat Prisma Dana Manado disajikan dalam Laporan Keuangan Laba 
Rugi Perusahaan. Disamping disajikan dalam Laporan Laba Rugi Beban atas Beban Administrasi dan Umum pada PT. Bank Perkreditan Rakyat Prisma Dana Manado harus diungkapkan pada catatan atas laporan keuangan.

\section{KESIMPULAN DAN SARAN \\ 5.1 Kesimpulan}

Berdasarkan hasil penelitian dan pembahasan yang telah dikemukakan sebelumnya, bahwa pengakuan pendapatan atas pendapatan bunga kontraktual dan pendapatan bunga provisi pada PT. Bank Perkreditan Rakyat Prisma Dana Manado diakui menggunakan metode cash basis dimana pendapatan diakui atau dicatat pada saat kas benar-benar diterima atau adanya penerimaan uang. Sedangkan pengakuan pendapatan atas pendapatan operasional lain pada PT. Bank Perkreditan Rakyat Prisma Dana Manado diakui menggunakan metode accrual basis dimana diakui pada saat terjadinya. Pengakuan beban atas beban penyisihan dan penyusutan, beban pemasaran, beban administrasi dan umum pada PT. Bank Perkreditan Rakyat Prisma Dana Manado diakui menggunakan metode accrual basis dimana seluruh biaya diakui sebagai beban pada laporan laba rugi di periode terjadinya, maka dapat diambil kesimpulan bahwa pengakuan pendapatan dan beban pada PT. Bank Perkreditan Rakyat Prisma Dana Manado ini telah sesuai dengan PSAK No. 23 karena PT. Bank Perkreditan Rakyat Prisma Dana Manado mengakui pendapatan dan beban dengan metode accrual basis dan cash basis, dimana PSAK No. 23 hanya mengakui dua metode yaitu accrual basis dan cash basis.

Pendapatan dan Beban pada PT. Bank Perkreditan Rakyat Prisma Dana Manado mengalami kenaikan dan penurunan di setiap tahunnya. Hal ini berdampak pada laba PT. Bank Perkreditan Rakyat Prisma Dana Manado. Pada tahun 2016, PT. Bank Perkreditan Rakyat Prisma Dana Manado, pendapatannya lebih besar daripada beban yang dikeluarkan, maka PT. Bank Perkreditan Rakyat Prisma Dana Manado mengalami peningkatan laba pada tahun tersebut. Sedangkan pada tahun 2015, PT. Bank Perkreditan Rakyat Prisma Dana Manado, beban yang dikeluarkan lebih besar daripada pendapatan yang diperoleh, maka dari itu PT. Bank Perkreditan Rakyat Prisma Dana Manado mengalami penurunan laba pada tahun tersebut.

\subsection{Saran} bahwa:

Berdasarkan analisis data yang telah dibahas sebelumnya, maka dapat disarankan

1. Dengan melihat keunggulan yang dimiliki accrual basis dalam penerapan akuntansinya maka PT. Bank Perkreditan Rakyat Prisma Dana Manado akan dapat membuat keputusan yang lebih baik serta laporan keuangan yang disajiikan oleh PT. Bank Perkreditan Rakyat Prisma Dana Manado dapat memberikan gambaran informasi akuntansi yang lebih akurat adanya kapan pendapatan dan beban diakui.

2. Untuk menghindari kesalahan pencatatan pada nominal pendapatan yang akan diterima dan beban yang dikeluarkan, diharapkan pihak PT. Bank Perkreditan Rakyat Prisma Dana Manado dapat meningkatkan ketelitian dalam melakukan pencatatan dan melakukan cek kembali setelah dilakukan pencatatan.

\section{DAFTAR PUSTAKA}

Baridwan, Zaki. 2014. Intermediate Accounting. Edisi Kedelapan: BPFE. Yogyakarta. Harahap, Sofyan. Syafri. 2011. Teori Akuntansi (edisi revisi 2011). Jakarta: Rajawali. Hendriksen, E. S. 2002. Teori Akuntansi. Edisi 5. Jilid 2. Jakarta: Erlangga. Hery. 2013. Akuntansi Dasar 1 dan 2. PT. Gramedia Widia Sarana Indonesia. Jakarta. 
Kieso, D. E., Weygandt, J. J., dan Warfield, T. D. 2016. Akuntansi Intermediate. Jakarta: Erlangga.

Soemarso. 2013. Akuntansi Suatu Pengantar. Salemba Empat. Jakarta.

Stice, James., dan Skousen, Freed. 2011. Akuntansi Keuangan Intermediate Accounting. Edisi 16. Salemba Empat. Jakarta.

Suwardjono. 2013. Teori Akuntansi Perekayasaan Pelaporan Keuangan edisi ketiga. BPFE. Yogyakarta.

Sugiyono. 2014. Metode Penelitian Kuantitatif, Kualitatif dan R\&D. Alfabeta. Bandung. Sukmadinata. 2013. Metode Penelitian Pendidikan. PT Remaja Rosdakarya. Bandung.. 